\title{
Field Test Program for Evaluation of Sorbent Injection for Mercury Control
}

\author{
Quarterly Technical Report \\ Reporting Period: October 1, 2003 - December 31, 2003
}

Principal Author:

Sharon Sjostrom

\author{
ADA-ES, Inc. \\ 8100 SouthPark Way, Unit B \\ Littleton, Colorado 80120
}

Submitted: February 12, 2004

DOE Cooperative Agreement No.: DE-FC26-03NT41986

Report No. 41986R01 


\section{DISCLAIMER}

This technical report was prepared with the support of the U.S. Department of Energy, under Award No. DE-FC26-03NT41986. However, any opinions, findings, conclusions, or recommendations expressed herein are those of the author(s) and do not necessarily reflect the views of the DOE.

This report was prepared as an account of work sponsored by an agency of the United States Government. Neither the United States Government nor any agency thereof, nor any of their employees, makes any warranty, express or implied, or assumes any legal liability or responsibility for the accuracy, completeness, or usefulness of any information, apparatus, product, or process disclosed, or represents that its use would not infringe privately owned rights. Reference herein to any specific commercial product, process, or service by trade name, trademark, manufacturer, or otherwise does not necessarily constitute or imply its endorsement, recommendation, or favoring by the United States Government or any agency thereof. The views and opinions of authors expressed herein do not necessarily state or reflect those of the United States Government or any agency thereof. 


\section{ABSTRACT}

The power industry in the U.S. is faced with meeting new regulations to reduce the emissions of mercury compounds from coal-fired plants. These regulations are directed at the existing fleet of nearly 1,100 boilers. These plants are relatively old with an average age of over 40 years. Although most of these units are capable of operating for many additional years, there is a desire to minimize large capital expenditures because of the reduced (and unknown) remaining life of the plant to amortize the project. Injecting a sorbent such as powdered activated carbon into the flue gas represents one of the simplest and most mature approaches to controlling mercury emissions from coal-fired boilers.

The overall objective of this test program described in this quarterly report is to evaluate the capabilities of activated carbon injection at four plants with configurations that together represent $78 \%$ of the existing coal-fired generation plants. This technology was successfully evaluated in NETL's Phase I tests at scales up to $150 \mathrm{MW}$, on plants burning subbituminous and bituminous coals and with ESPs and fabric filters. The tests also identified issues that still need to be addressed, such as evaluating performance on other configurations, optimizing sorbent usage (costs), and gathering longer term operating data to address concerns about the impact of activated carbon on plant equipment and operations. The four sites identified for testing are Sunflower Electric's Holcomb Station, AmerenUE's Meramec Station, AEP's Conesville Station, and Ontario Power Generation's Nanticoke Station.

This is the first quarterly report for this project. This report includes an overview of the plans for the project. Field testing is scheduled to begin next quarter. In general, quarterly reports will be used to provide project overviews, project status, and technology transfer information. Topical reports will be prepared to present detailed technical information. 


\section{TABLE OF CONTENTS}

LIST OF GRAPHICAL MATERIALS ...................................................................... iv

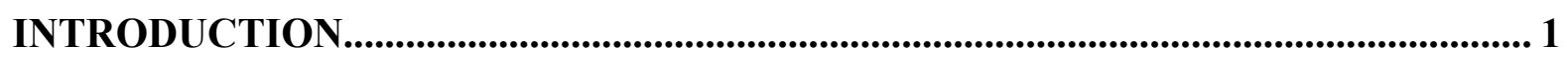

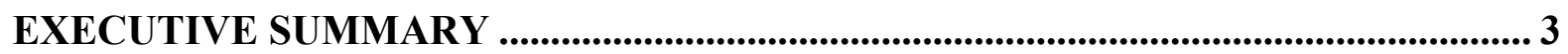

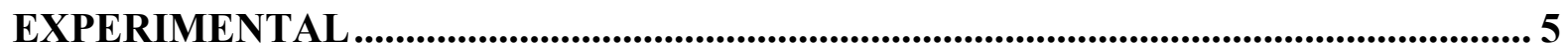

Task 1. Design and Fabrication of Sorbent Injection System....................................... 5

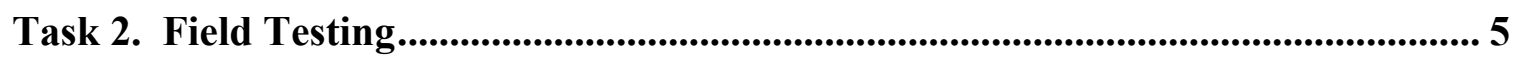

Task 3. Technology Transfer .......................................................................... 10

Task 4. Program Management and Reporting..................................................... 10

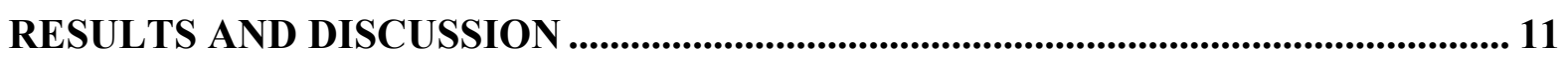

Task 1. Design and Fabrication of Sorbent Injection System..................................... 11

Task 2. Field Testing............................................................................................... 11

Task 3. Technology Transfer .................................................................................. 11

Task 4. Program Management and Reporting................................................................. 11

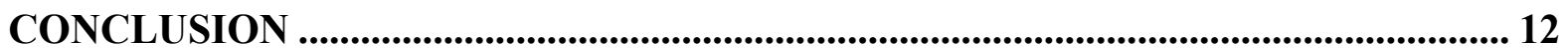

REFERENCES...................................................................................................... 13

LIST OF ACRONYMS AND ABBREVIATIONS ................................................. 14 


\section{LIST OF GRAPHICAL MATERIALS}

Table 1. Host Site Key Descriptive Information. ................................................................ 2

Table 2. Host Sites Participating in the Sorbent Injection Demonstration

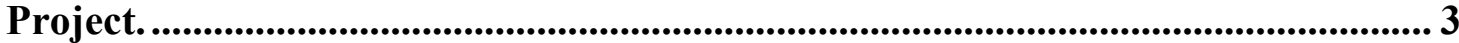

Table 3. Task 2 Subtasks (to be repeated at each test site). ...............................................5 


\section{INTRODUCTION}

The overall objective of this test program is to evaluate the capabilities of activated carbon injection at four plants with configurations that together represent $78 \%$ of the existing coalfired generation plants. This technology was successfully evaluated in NETL's Phase I tests at scales up to $150 \mathrm{MW}$, on plants burning subbituminous and bituminous coals and with ESPs and fabric filters. The tests also identified issues that still need to be addressed, such as evaluating performance on other configurations, optimizing sorbent usage (costs) and gathering longer-term operating data to address concerns about the impact of activated carbon on plant equipment and operations. A summary of the key descriptive parameters for the host sites can be found in Table 2 .

A technical approach that is described in this section will allow the team to: 1) effectively evaluate activated carbon and other viable sorbents on a variety of coals and plant configurations, and 2) perform long-term testing at the optimum condition for at least one month. These technical objectives will be accomplished by following a series of technical tasks:

Task 1. Design and Fabrication of Sorbent Injection System

Task 2. Field Testing (Four Sites)

Task 3. Technology Transfer

Task 4. Program Management and Reporting

Tasks 1, 3, and 4 are intended to support the overall direction, implementation, technology transfer, and management of the program. Task 2 will be repeated for each test site with subtasks designed to address the specific configurations, needs, and challenges of that site. Task 2 is the heart of the program and contains subtasks to address each important component of the testing. A summary of the Field Testing subtasks (Task 2) is presented in Table 3. 
Table 1. Host Site Key Descriptive Information.

\begin{tabular}{|l|l|l|l|l|}
\hline & Holcomb & Meramec & Nanticoke & Conesville \\
\hline Unit & 1 & 1 or 2 & 5 or 6 & 5 or 6 \\
\hline Size $(\mathrm{MW})$ & 360 & 140 & 500 & 400 \\
\hline Coal & PRB & PRB & PRB & Bituminous \\
\hline Heating Value (as received) & 8,700 & 8,738 & 8,840 & 11,040 \\
\hline Sulfur $\%$ by weight) & 0.4 & 0.25 & 0.5 & 2.45 \\
\hline Chlorine (\%) & $<0.05$ & 0.06 & $<0.05$ & $0.06-0.16$ \\
\hline Mercury $(\mu \mathrm{g} / \mathrm{g})$ & 0.056 & 0.052 & 0.075 & 0.16 \\
\hline Particulate Control & $\begin{array}{l}\text { Joy Western } \\
\text { Fabric Filter }\end{array}$ & $\begin{array}{l}\text { American Air } \\
\text { Filter ESP }\end{array}$ & $\begin{array}{l}\text { ESP } \\
\text { Joy Western }\end{array}$ & $\begin{array}{l}\text { Research- } \\
\text { Cottrell ESP }\end{array}$ \\
\hline SCA (ft $/$ kacfm) & NA & 400 & 208 & 301 \\
\hline Sulfur Control & $\begin{array}{l}\text { Spray Dryer } \\
\text { Niro Joy } \\
\text { Western }\end{array}$ & $\begin{array}{l}\text { Compliance } \\
\text { Coal }\end{array}$ & $\begin{array}{l}\text { Compliance } \\
\text { Coal }\end{array}$ & $\begin{array}{l}\text { Wet Lime } \\
\text { FGD }\end{array}$ \\
\hline Ash Reuse & Disposal & $\begin{array}{l}\text { Sold for } \\
\text { concrete }\end{array}$ & Sold & $\begin{array}{l}\text { FGD Sludge } \\
\text { Stabilization }\end{array}$ \\
\hline Test Portion (MWe) & 165 and 330 & 140 & 250 and 500 & 400 \\
\hline Typical Inlet Mercury $(\mu \mathrm{g} /$ dncm) & $10-11$ & $10($ estimate) & $8-9$ & 15.8 \\
\hline Typical Mercury Removal & $13 \%$ & $\begin{array}{l}10-20 \% \\
(\text { estimate) }\end{array}$ & $35 \%$ & $56 \%$ \\
\hline
\end{tabular}

A detailed topical report will be prepared at the end of the one-year test period. Quarterly reports will be used to provide project overviews, status, and technology transfer information. 


\section{EXECUTIVE SUMMARY}

This four-site project is part of an overall program funded by the Department of Energy's National Energy Technology Laboratory (NETL) and industry partners to obtain the necessary information to assess the feasibility and costs of controlling mercury from coalfired utility plants. Host sites that will be tested as part of this program are shown in Table 1. These host sites reflect a combination of coals and existing air pollution control configurations representing $78 \%$ of existing coal-fired generating plants and potentially a significant portion of new plants. These four host sites will allow documentation of sorbent performance on the following configurations:

Table 2. Host Sites Participating in the Sorbent Injection Demonstration Project.

\begin{tabular}{|l|l|l|l|l|}
\hline & Coal / Options & APC & $\begin{array}{c}\text { Capacity } \\
\text { MW / Test Portion }\end{array}$ & $\begin{array}{l}\text { Current Hg } \\
\text { Removal (\%)* }\end{array}$ \\
\hline $\begin{array}{l}\text { Sunflower Electric's } \\
\text { Holcomb Station }\end{array}$ & PRB \& Blend & SDA - Fabric Filter & $\begin{array}{l}360 / 180 \text { and } \\
360 / 360\end{array}$ & 13 \\
\hline $\begin{array}{l}\text { Ontario Power } \\
\text { Generation's } \\
\text { Nanticoke Station }\end{array}$ & PRB \& Blend & ESP & $\begin{array}{l}500 / 250 \text { and } \\
500 / 500\end{array}$ & 35 \\
\hline $\begin{array}{l}\text { AmerenUE's } \\
\text { Meramec Station }\end{array}$ & PRB & ESP & $140 / 70$ & $\begin{array}{l}10-20 \\
\text { (estimate) }\end{array}$ \\
\hline $\begin{array}{l}\text { American Electric } \\
\text { Power's (AEP) } \\
\text { Conesville Station }\end{array}$ & Bituminous Blend & ESP + Wet FGD & $400 / 400$ & 56 \\
\hline
\end{tabular}

* Based upon recent Ontario Hydro measurements, except Meramec.

During the first reporting quarter, October through December 2003, progress on the project was made in the following areas:

\section{Overall}

- Held the Project Kickoff Meeting

\section{Sunflower Electric Power Corporation, Holcomb Station}

- Issued a draft Test Plan

- Held an on-site Kickoff Meeting

- Issued a draft Installation Document

- Finalize design for injection skid

- Submitted Host Site and Cost-Share agreements to Sunflower Electric

- Issued invitations to sorbent producers and developers to submit sorbent samples for testing 
AmerenUE, Meramec

- Conducted a site visit

- Submitted a plan for new port locations

- Submitted Host Site agreement to AmerenUE

American Electric Power (AEP), Conesville

- Conducted a site visit and introductory meeting

Ontario Power Generation, Nanticoke

- Conducted a site visit 


\section{EXPERIMENTAL}

The overall objective of this test program is to evaluate the capabilities of activated carbon injection at four plants with configurations that together represent $78 \%$ of the existing coalfired generation plants. Following the technical approach summarized in this section, ADA-ES and the project team will evaluate activated carbon and other viable sorbents on a variety of coals and plant configurations, and perform long-term testing at the optimum condition for up to six weeks. The technical approach is outlined in a series of four technical tasks:

\section{Task 1. Design and Fabrication of Sorbent Injection System}

ADA-ES, the primary test contractor, will provide the majority of the process equipment that will travel from site to site. This equipment will be sized and designed to cover the expected range of plant sizes (140-500 MW) and flue gas conditions, and has the flexibility for both baghouse and ESP applications.

\section{Task 2. Field Testing}

This task will be repeated four times for the site-specific field tests at the four host sites. Each Field Testing task has seven subtasks that will be repeated at each site. A summary of the Field Testing subtasks is presented in Table 3. The four sites identified for testing are Sunflower Electric's Holcomb Station, AmerenUE's Meramec Station, AEP's Conesville Station and Ontario Power Generation's Nanticoke Station. Specific host site task details follow.

Table 3. Task 2 Subtasks (to be repeated at each test site).

\begin{tabular}{|l|l|}
\hline Subtask & Description \\
\hline 2.1 & Host site kickoff meeting, test plan, and QA/QC plan \\
\hline 2.2 & Design and install site-specific equipment \\
\hline 2.3 & Field tests \\
2.3 .1 & Sorbent screening \\
2.3 .2 & Sample and data coordination \\
2.3 .3 & Baseline tests \\
2.3 .4 & Parametric tests \\
2.3 .5 & Long-term tests \\
\hline 2.4 & Data analysis \\
\hline 2.5 & Sample evaluation \\
\hline 2.6 & Economic analysis \\
\hline 2.7 & Site report \\
\hline
\end{tabular}




\section{Sunflower Electric's Holcomb Station, Unit 1}

Holcomb Station is located in Garden City, Kansas. The unit is a load-following sub-critical 360-MW pulverized coal opposed-fired Babcock \& Wilcox Carolina-type radiant boiler designed to burn PRB coal. The existing unit is equipped with a single spray dry absorber followed by two very low air/cloth ratio reverse air fabric filters. For activated carbon injection testing with injection upstream of the spray dryer, the entire 360-MW unit would be evaluated. If no difference is noted between injection upstream or downstream of the spray dryer, a single fabric filter module (one-half of the unit) could be evaluated. In addition, the coal handling equipment could be modified to allow co-firing with 10 to $15 \%$ bituminous coal.

In 2002, Holcomb 1 unit underwent substantial emissions testing, including the measurement of gaseous hazardous air pollutants and the measurement of mercury removal across the fabric filter by way of a semi-continuous mercury emission analyzer. The unit is also uniquely equipped with instrument sensors installed in conjunction with DE-FC2603NT41418, which will enable the measurement and control of critical combustion parameters.

\section{Ontario Power Generation's Nanticoke Generating Station}

Nanticoke Generating Station is located on the north shore of Lake Erie near Hamilton, Ontario, Canada. Nanticoke is one of the largest coal-fired facilities in the world with a generation capacity of 4,000 MW across eight 500-MW units. The boilers are B\&Wdesigned PC units that normally fire a blend of PRB and low-sulfur eastern bituminous coals. Boiler flue gas passes through an air preheater and ESP before venting through the stack. This unit provides the opportunity to evaluate an ESP with an SCA of nominally 210 $\mathrm{ft}^{2} / \mathrm{kacfm}$.

Because of the duct configuration, parametric testing will have to be conducted across the entire 500-MW unit. During long-term tests, it is anticipated that sorbent will only be injected in one-half of the unit $(250 \mathrm{MW})$. In addition, it is important to this site that we minimize the potential loss of ash sales. To do this, the long-term tests will be kept to the minimum allowable time.

\section{AmerenUE's Meramec Unit 1 or 2}

AmerenUE's Meramec Plant is located in St. Louis County, Missouri. Units 1 and 2 are both load-following, sub-critical 140-MW (gross) pulverized coal, tangentially fired, steamelectric generating units that operate at a $60 \%$ capacity factor. The units were originally designed to fire high-sulfur, Illinois bituminous coal, but now combust $100 \%$ subbituminous PRB coal. Each unit is equipped with an electrostatic precipitator (ESP) for particulate removal. During the upcoming 2004 spring outage, both units will be retrofitted with Low $\mathrm{NO}_{\mathrm{x}}$ burners and separated overfire air for control of $\mathrm{NO}_{\mathrm{x}}$ emissions. For PAC injection testing with injection upstream of the ESP, only one of the two units will be evaluated.

Mercury testing has previously been conducted at Meramec Plant and these results were included in the ICR data. However, this testing was conducted prior to the station's decision to fuel switch entirely over to $100 \%$ PRB coal. Therefore, some testing would be necessary 
over the next several months to establish a representative baseline. In lieu of actual test data, we currently base our assumptions on ICR data for similar generating units that combust PRB coal with a medium-size ESP as a representative estimate of the current mercury emissions from these units.

Unlike many sites that sell their ash for use in concrete and were considered for inclusion in this program, the ash from Units 1 and 2 can be collected and disposed of separately from ash from the other units. For the long-term tests, this is a key consideration. It would be possible to operate for an extended period at this site.

\section{AEP's Conesville Unit 5 or 6}

AEP Conesville Units 5 and 6 are sister 400-MW T-fired units located in Conesville, Ohio. The boilers are Combustion Engineering (ALSTOM) designed PC units that normally fire high-sulfur eastern bituminous coal. The units are each equipped with cold-side ResearchCottrell ESPs. Flue gas is drawn through the ESPs via ID fans. In each unit, the ID fans discharge flue gas into two Universal Oil Products wet lime absorber modules. The modules have partial bypass capability and have been retrofitted with a B\&W tray design. Testing is planned for one 400-MW unit.

\section{Subtask 2.1. Host Site Planning and Coordination}

Efforts within this subtask include planning the site-specific tests with the host site utility, DOE/NETL, and contributing team members. The planning process includes meeting with plant personnel, corporate, and environmental personnel to discuss and agree upon the overall scope of the program, the potential impact on plant equipment and operation, and to gather preliminary information necessary to develop a detailed draft test plan and scope of work. Efforts include identifying any permit requirements, developing a quality assurance/quality control plan, finalizing the site-specific scope for each of the team members, and putting subcontracts in place for Ontario Hydro mercury measurement services.

A key component of the planning process for these evaluations is identifying potential sorbents for testing. The test program at each site allows for the evaluation of different sorbents because of the economic impact of sorbent cost on the overall cost of mercury control and disposal considerations. In addition, sorbents that have the potential to capture mercury at the low $\mathrm{HCl}$ conditions typical of subbituminous units, especially those with upstream spray dryers, will be evaluated.

\section{Subtask 2.2. Design, Fabricate, and Install Site-Specific Equipment}

Some components are site-specific and, by necessity, will be provided by the host utility. These are components that must be sized and designed for the specific plant arrangements and ductwork configurations. Site-specific equipment includes the sorbent distribution manifold and sorbent injectors (if possible these components will be reused at multiple sites). Required site support includes installation of the injection and sampling ports (if not available), installation of required platforms and scaffolding, compressed air, electrical power, wiring plant signals including boiler load to the injection skid and control trailer, and 
the balance of plant engineering. The host utility will be responsible for all permitting and any variance requirements.

\section{Subtask 2.3. Field Tests}

The field tests will be accomplished through a series of five (5) subtasks. A summary of each task is presented.

\subsubsection{Sorbent Screening:}

Prior to the start of equipment installation, selected sorbents will be screened on actual flue gas.

\subsubsection{Sample and Data Coordination:}

ADA-ES engineers will coordinate with plant personnel to retrieve the necessary plant operating data files. These data will be integrated into the sorbent injection and mercury control data.

\subsubsection{Baseline Testing:}

Once the equipment is installed, a set of baseline tests will be conducted just prior to the parametric testing. Unit operation will be set at conditions expected during the parametric tests. It is anticipated that boiler load will be held constant at full-load and that the air pollution equipment will be operated under standard full-load conditions (standard soot blowing, baghouse cleaning logic, spray dryer recycle, ESP rapping, etc., will be used). Ontario Hydro mercury measurements will be conducted in conjunction with SCEM measurements during this subtask.

For sites with the ability to co-fire with a blend of bituminous and PRB coals, tests will be conducted to measure the effect of partial co-firing with a bituminous coal on both mercury removal and speciation across the particulate control devices. Mercury measurements will be made using only the SCEMs.

\subsubsection{Parametric Tests:}

The goals of this task are to define the quantity of sorbent required to obtain different levels of mercury removal, such as $60 \%, 80 \%$, and $90 \%$ of the remaining mercury. Up to four weeks of parametric testing will be conducted, depending on the host site test plan. A condition is typically tested for about 8 hours, and then the system is shut down and allowed to return to baseline conditions before the next parametric test.

\subsubsection{Long-Term Testing:}

Long-term testing will be conducted at the "optimum" settings as determined in the parametric tests and approved by both DOE and the host utility. It is the intent of DOE that these settings represent the maximum mercury removal. The goal of this task is to obtain sufficient operational data on removal efficiency over a 4- to 6-week period, the effects on the particulate control device, the effects on the sulfur control equipment, effects on 
byproducts, and impacts to the balance of plant equipment to prove viability of the process and determine the economics. During this test, Ontario Hydro measurements will be conducted at the inlet and outlet of the pollution control device(s) at least once, depending on results verifying SCEM measurements during the baseline tests.

\section{Subtask 2.4. Data Analysis}

Data collection and analysis for this program is designed to measure the effect of sorbent injection on mercury control and the impact on the existing pollution control equipment. The mercury levels and plant operation will be characterized without sorbent injection, during coal blending (when applicable), and with various injection rates and possible combustion modifications as defined by the final test plan, and a long-term evaluation to identify effects that may not be immediate.

\section{Subtask 2.5. Coal and Byproduct Evaluation}

Coal and combustion byproduct samples collected throughout the field test will be analyzed in this task. During all test phases, samples of coal, fly ash, and scrubber waste will be collected. Ultimate and proximate analyses will be performed and mercury, chlorine, and sulfur levels will be determined. Activated carbon injection will result in the fly ash and scrubber materials being mixed with a certain amount of the mercury-containing sorbent. The ash samples will be analyzed at a minimum for mercury and LOI. Scrubber feed limestone, solids product discharge, and blowdown will be analyzed for mercury. Because of the apparent influence of $\mathrm{HCl}$ on sorbent effectiveness, $\mathrm{HCl}$ measurements will be conducted and samples analyzed to determine if there is a correlation between sorbent effectiveness and $\mathrm{HCl}$ concentrations.

Standard leaching test methods will include the Toxicity Characteristic Leaching Procedure (TCLP, SW846-1311) and synthetic groundwater leaching procedure (SGLP).

Analytical tests to determine if the ash is suitable for use in concrete will be conducted at Nanticoke and Meramec. Tests are conducted to evaluate properties under ASTM Specification C618, which include chemical and physical property analysis. Air entrainment shaker tests will also be performed as part of the concrete suitability test series.

A site report will be prepared documenting measurements, test procedures, analyses, and results obtained in Task 2 . This report is intended to be a stand-alone document providing a comprehensive review of the testing that will be submitted to the host utility.

\section{Subtask 2.6. Economic Analysis}

After completion of testing and analysis of the data at each plant, the requirements and costs for full-scale permanent commercial implementation of the selected mercury control technology will be determined. The ADA-ES/ALSTOM program team will meet with the host utility plant and engineering personnel to develop plant-specific design criteria. Process equipment will be sized and designed based on test results and the plant-specific requirements (reagent storage capacity, plant arrangement, retrofit issues, winterization, controls interface, etc.). A conceptual design document will be developed. Finally, a budget cost estimate will be developed to implement the control technology. 


\section{Subtask 2.7. Site Report}

A site report will be prepared documenting measurements, test procedures, analyses, and results obtained in Task 2. This report is intended to be a stand-alone document providing a comprehensive review of the testing that will be submitted to the host utility.

\section{Task 3. Technology Transfer}

Technology transfer activities include participation in DOE/NETL sponsored meetings, EPA Hg MACT Stakeholder meetings, presentations at conferences, and publication of technical papers.

\section{Task 4. Program Management and Reporting}

The final task provides time for overall program management and time to complete DOE's reporting requirements. This task will also support periodic meetings with DOE to discuss progress and obtain overall direction of the program from the DOE project manager. In addition to the standard financial and technical reports, additional deliverables will include topical reports for each site tested. 


\section{RESULTS AND DISCUSSION}

\section{Task 1. Design and Fabrication of Sorbent Injection System}

- Design of the sorbent injection system will be completed in February 2004

\section{Task 2. Field Testing}

- Site visits to each of the host sites were conducted during this reporting period.

\section{Sunflower Electric Power Corporation, Holcomb Station}

- Issued a draft Test Plan

- Held an on-site Kickoff Meeting

- Issued a draft Installation Document

- Finalize design for injection skid

- Submitted Host Site and Cost-Share agreements to Sunflower Electric

- Issued invitations to sorbent producers and developers to submit sorbent samples for testing

\section{AmerenUE, Meramec}

- Conducted a site visit

- Submitted a plan for new port locations

- Submitted Host Site agreement to AmerenUE

\section{American Electric Power (AEP), Conesville}

- Conducted a site visit and introductory meeting

\section{Ontario Power Generation, Nanticoke}

- Conducted a site visit

\section{Task 3. Technology Transfer}

No activities this quarter.

\section{Task 4. Program Management and Reporting}

The project kickoff meeting was conducted in November 2003. 


\section{CONCLUSION}

None this reporting period. 


\section{REFERENCES}

None this reporting period. 


\section{LIST OF ACRONYMS AND ABBREVIATIONS}

$\begin{array}{ll}\text { ACI } & \text { Activated carbon injection } \\ \text { APC } & \text { Air pollution control } \\ \text { B\&W } & \text { Babcock \& Wilcox } \\ \text { DOE } & \text { Department of Energy } \\ \text { ESP } & \text { Electrostatic precipitator } \\ \text { FGD } & \text { Flue gas desulfurization } \\ \text { ID Fan } & \text { Induced draft fan } \\ \text { kacfm } & \text { Thousand actual cubic feet per minute } \\ \text { kW } & \text { Kilowatt } \\ \text { MW } & \text { Megawatt } \\ \text { NETL } & \text { National Energy Technology Laboratory } \\ \text { O\&M } & \text { Operating and Maintenance } \\ \text { PC } & \text { Pulverized coal } \\ \text { PRB } & \text { Powder River Basin } \\ \text { SCA } & \text { Specific collection area } \\ \text { SCEM } & \text { Semi-continuous emission monitor } \\ \text { SDA } & \text { Spray dryer absorber } \\ \text { SGLP } & \text { Synthetic groundwater leaching procedure } \\ \text { TCLP } & \text { Toxicity characteristic leaching procedure }\end{array}$

